\title{
Front Matter: Volume 8517
}

, "Front Matter: Volume 8517," Proc. SPIE 8517, Laser Communication and Propagation through the Atmosphere and Oceans, 851701 (24 October 2012); doi: $10.1117 / 12.2008670$

Event: SPIE Optical Engineering + Applications, 2012, San Diego, California, United States 


\title{
Laser Communication and Propagation through the Atmosphere and Oceans
}

\author{
Alexander M. J. van Eijk \\ Christopher C. Davis \\ Stephen M. Hammel \\ Arun K. Majumdar \\ Editors
}

13-15 August 2012

San Diego, California, United States

Sponsored and Published by

SPIE 
The papers included in this volume were part of the technical conference cited on the cover and title page. Papers were selected and subject to review by the editors and conference program committee. Some conference presentations may not be available for publication. The papers published in these proceedings reflect the work and thoughts of the authors and are published herein as submitted. The publisher is not responsible for the validity of the information or for any outcomes resulting from reliance thereon.

Please use the following format to cite material from this book:

Author(s), "Title of Paper," in Laser Communication and Propagation through the Atmosphere and Oceans, edited by Alexander M. van Eijk, Christopher C. Davis, Stephen M. Hammel, Arun K. Majumdar, Proceedings of SPIE Vol. 8517 (SPIE, Bellingham, WA, 2012) Article CID Number.

ISSN: 0277-786X

ISBN: 9780819492340

Published by

SPIE

P.O. Box 10, Bellingham, Washington 98227-0010 USA

Telephone +1 3606763290 (Pacific Time) · Fax +1 3606471445

SPIE.org

Copyright (C) 2012, Society of Photo-Optical Instrumentation Engineers.

Copying of material in this book for internal or personal use, or for the internal or personal use of specific clients, beyond the fair use provisions granted by the U.S. Copyright Law is authorized by SPIE subject to payment of copying fees. The Transactional Reporting Service base fee for this volume is $\$ 18.00$ per article (or portion thereof), which should be paid directly to the Copyright Clearance Center (CCC), 222 Rosewood Drive, Danvers, MA 01923. Payment may also be made electronically through CCC Online at copyright.com. Other copying for republication, resale, advertising or promotion, or any form of systematic or multiple reproduction of any material in this book is prohibited except with permission in writing from the publisher. The CCC fee code is 0277-786X/12/\$18.00.

Printed in the United States of America.

Publication of record for individual papers is online in the SPIE Digital Library.

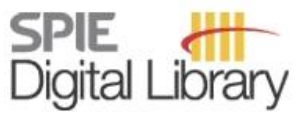

SPIEDigitalLibrary.org

Paper Numbering: Proceedings of SPIE follow an e-First publication model, with papers published first online and then in print and on CD-ROM. Papers are published as they are submitted and meet publication criteria. A unique, consistent, permanent citation identifier (CID) number is assigned to each article at the time of the first publication. Utilization of CIDs allows articles to be fully citable as soon as they are published online, and connects the same identifier to all online, print, and electronic versions of the publication. SPIE uses a six-digit CID article numbering system in which:

- The first four digits correspond to the SPIE volume number.

- The last two digits indicate publication order within the volume using a Base 36 numbering

system employing both numerals and letters. These two-number sets start with 00, 01, 02, 03, 04,

$05,06,07,08,09,0 A, 0 B \ldots$. OZ, followed by 10-1Z, 20-2Z, etc.

The CID Number appears on each page of the manuscript. The complete citation is used on the first page, and an abbreviated version on subsequent pages. Numbers in the index correspond to the last two digits of the six-digit CID Number. 


\section{Contents}

vii Conference Committee

\section{SESSION 1 FREE-SPACE OPTICAL DEMONSTRATION AND ANALYSIS}

851703 Communication system technology for demonstration of BB84 quantum key distribution in optical aircraft downlinks [8517-2]

F. Moll, Deutsches Zentrum für Luft- und Raumfahrt e.V. (Germany); S. Nauerth, LudwigMaximilians-Univ. München (Germany); C. Fuchs, J. Horwath, Deutsches Zentrum für Luftund Raumfahrt e.V. (Germany); M. Rau, Ludwig-Maximilians-Univ. München (Germany); H. Weinfurter, Ludwig-Maximilians-Univ. München (Germany) and Max-Planck-Institut für Quantenoptik (Germany)

851704 A stereo PTZ tracking and surveillance system with two dynamic cameras operating in a master-slave relationship [8517-3]

M. Eslami, J. Rzasa, C. C. Davis, Univ. of Maryland, College Park (United States)

851705 A novel prediction methodology for detecting failures and instabilities in directional wireless networks [8517-4]

D. M. Coleman, S. D. Milner, C. C. Davis, Univ. of Maryland, College Park (United States)

851706 Transportable optical ground station for high-speed free-space laser communication [8517-5]

A. Shrestha, M. Brechtelsbaver, German Aerospace Ctr., Deutsches Zentrum für Luft- und Raumfahrt e.V. (Germany)

851707 Measurements and comparison of the probability density and covariance functions of laser beam intensity fluctuations in a hot-air furbulence emulator with the maritime atmospheric environment [8517-6]

C. Nelson, The Johns Hopkins Univ. (United States) and U.S. Naval Academy (United States);

S. Avramov-Zamurovic, R. Malek-Madani, U.S. Naval Academy (United States);

O. Korotkova, Univ. of Miami (United States); R. Sova, The Johns Hopkins Univ. Applied

Physics Lab. (United States); F. Davidson, The Johns Hopkins Univ. (United States)

\section{SESSION $2 \quad$ FREE-SPACE OPTICAL MODELS AND DEVICES}

851708 Demonstration of multi-user laser communication using orbital-angular-momentum channels [8517-7]

J. A. Anguita, C. Quezada, J. Herreros, Univ. de Los Andes (Chile)

$851709 \quad$ NLOS UV channel modeling using numerical integration and an approximate closed-form path loss model [8517-8]

A. Gupta, M. Noshad, M. Brandt-Pearce, Univ. of Virginia (United States) 
$85170 \mathrm{~A}$ Spectral analysis of encrypted chaotic signals using fast Fourier transforms and laboratory spectral analyzers [8517-9]

M. R. Chatterjee, A. Kundur, Univ. of Dayton (United States)

8517 OD Non-line-of-sight ultraviolet communication based on DHT ACO-OFDM [8517-12]

Q. Gao, G. Chen, Univ. of California, Riverside (United States)

8517 OF High-data rate differential phase shift keying receiver for satellite-to-ground optical communication link [8517-14]

Y. Zhi, J. Sun, E. Dai, Y. Zhou, L. Wang, W. Lu, P. Hou, L. Liu, Shanghai Institute of Optics and Fine Mechanics (China)

\section{SESSION 3 OPTICAL PROPAGATION IN TURBULENCE}

8517 OG Long- and short-term scintillation of the focused beams and point spread functions in turbulent atmosphere [8517-15]

M. Charnotskii, Zel Technologies, LLC (United States) and NOAA/Earth System Research Lab. (United States); G. J. Baker, Lockheed Martin Advanced Technology Ctr. (United States)

$8517 \mathrm{OH}$ Turbulence simulation in diverse conditions for FSO Links [8517-16]

H. Yuksel, Bogazici Univ. (Turkey); H. Meric, Bilkent Univ. (Turkey)

8517 ol Study of strong turbulence effects for optical wireless links [8517-17]

H. Yuksel, Bogazici Univ. (Turkey); H. Meric, Bilkent Univ. (Turkey); F. Kunter, Marmara Univ. (Turkey)

$85170 \mathrm{~J}$ Estimation of the atmospheric blurring function using blind image quality metrics [8517-18] J. P. Bos, M. C. Roggemann, Michigan Technological Univ. (United States)

8517 OK Investigation of seasonal and diurnal cycles on the height dependence of optical turbulence in the lower atmospheric boundary layer [8517-19]

D. Sprung, P. Grossmann, E. Sucher, Fraunhofer-Institut für Optronik, Systemtechnik und Bildauswertung (Germany)

$8517 \mathrm{OL}$ Improved vertical refractive-index structure parameter model for the maritime atmosphere based on local bulk meteorological measurements [8517-20]

C. N. Reinhardt, S. M. Hammel, K. McBryde, D. Tsintikidis, Space and Naval Warfare Systems Ctr. (United States)

\section{SESSION 4 TURBULENCE MODELS AND MITIGATION}

8517 OM Reciprocity-enhanced optical communication through atmospheric turbulence - part I: reciprocity proofs and far-field power transfer optimization [8517-21]

J. H. Shapiro, Massachusetts Institute of Technology (United States); A. Puryear, MIT Lincoln Lab. (United States) 
8517 ON Reciprocity-enhanced optical communication through atmospheric turbulence - part II: communication architectures and performance [8517-22]

A. L. Puryear, MIT Lincoln Lab. (United States); J. H. Shapiro, Massachusetts Institute of

Technology (United States); R. R. Parenti, MIT Lincoln Lab. (United States)

851700 Optical propagation in a turbulent atmosphere using the split step method [8517-23]

H. Yuksel, Bogazici Univ. (Turkey); F. C. Kunter, Marmara Univ. (Turkey)

8517 OP Propagation of Gaussian beams through a modified von Karman phase screen [8517-24] E. M. Whitfield, P. P. Banerjee, J. W. Haus, Univ. of Dayton (United States)

\section{SESSION 5 ATMOSPHERIC CHANNEL MODELING AND OPTIMIZATION}

8517 OS Using a plenoptic camera to measure distortions in wavefronts affected by atmospheric turbulence [8517-27]

M. Eslami, C. Wu, J. Rzasa, C. C. Davis, Univ. of Maryland, College Park (United States)

8517 OT Analysis of optical communications through the random air-water interface: feasibility for under-water communications [8517-28]

A. K. Majumdar, J. Siegenthaler, P. Land, Naval Air Warfare Ctr. (United States)

8517 OU Highly validated atmospheric water vapor vertical profiles using Raman lidar technique [8517-29]

W. Al-Basheer, K. B. Strawbridge, Environment Canada (Canada)

8517 OV Modeling off-axis laser scattering: effects from aerosol distributions [8517-30]

J. S. deGrassie, SPAWAR Systems Ctr. Pacific (United States)

\section{SESSION 6 ADAPTIVE TECHNIQUES AND CHANNEL COMPENSATION}

8517 OW Phase discrepancy induced from least squares wavefront reconstruction of wrapped phase measurements with high noise or large localized wavefront gradients [8517-31] M. J. Steinbock, M. W. Hyde, Air Force Institute of Technology (United States)

8517 OX Capacity of adaptive free-space optical channel using bi-directional links [8517-32] A. Khatoon, W. G. Cowley, Univ. of South Australia (Australia); N. Letzepis, Defence Science and Technology Organisation (Australia)

8517 OY Beacon-defined performance of adaptive optics [8517-34]

A. Khizhnyak, V. Markov, J. Chavez, S. Liu, Advanced Systems \& Technologies, Inc. (United States)

$85170 Z$ Heterogeneous optical networking using orthogonal OAM multimode modulation [8517-35] I. B. Djordjevic, The Univ. of Arizona (United States); J. Anguita, Univ. de Los Andes (Chile)

851710 Probability distributions of link durations with $\boldsymbol{n}$ disruptive channels: application to groundspace optical communications [8517-36]

N. Perlot, F. Moll, Deutsches Zentrum für Luft- und Raumfahrt e.V. (Germany) 
851711 Extended model of restricted beam for FSO links [8517-37]

J. Poliak, O. Wilfert, Brno Univ. of Technology (Czech Republic)

851712 Estimation of turbulence characteristic scales in a water cell [8517-38]

V. A. Kulikov, A. M. Obukhov Institute of Atmospheric Physics (Russian Federation);

M. S. Andreeva, V. I. Shmalhausen, Lomonosov Moscow State Univ. (Russian Federation)

POSTER SESSION

851713 High-data rate laser communication field experiment in the turbulence channel [8517-39]

J. Sun, Y. Zhi, W. Lu, L. Wang, E. Dai, L. Liu, Shanghai Institute of Optics and Fine Mechanics (China)

851714 Technological research of differential phase shift keying receiver in the satellite-to-ground laser communication [8517-40]

X. Ma, J. Sun, Y. Zhi, L. Liu, Shanghai Institute of Optics and Fine Mechanics (China)

851715 Polarization phase-shifting cyclic Jamin shearing interferometer [8517-41]

L. Wang, L. Liu, J. Sun, Y. Zhou, E. Dai, Y. Wu, Shanghai Institute of Optics and Fine Mechanics (China)

851716 Physical and statistical modeling of attenuation due to atmospheric hydrometeors on freespace optical links at 850 and $1550 \mathrm{~nm}$ [8517-42]

M. Grabner, V. Kvicera, Czech Metrology Institute (Czech Republic)

851717 Phase-space analysis of laser beam propagation within atmospheric turbulence [8517-43]

W. Lu, J. Sun, D. XU, Y. Wu, X. Ma, B. Li, L. Liu, Institute of Optics and Fine Mechanics (China) and Key Lab. of Space Laser Communication and Testing Technology (China)

Author Index 


\section{Conference Committee}

Program Track Chairs

Stephen M. Hammel, Space and Naval Warfare Systems Command (United States)

Alexander M. J. van Eijk, TNO Defence, Security and Safety (Netherlands)

Conference Chairs

Alexander M. J. van Eijk, TNO Defence, Security and Safety (Netherlands)

Christopher C. Davis, University of Maryland, College Park (United States)

Stephen M. Hammel, Space and Naval Warfare Systems Command (United States)

Arun K. Majumdar, Naval Air Warfare Center Weapons Division (United States)

Conference Program Committee

Larry C. Andrews, University of Central Florida (United States)

Jaime A. Anguita, Universidad de Los Andes (Chile)

Shlomi Arnon, Ben-Gurion University of the Negev (Israel)

Mikhail S. Belen'kii, Trex Enterprises Corporation (United States)

Matthew M. Bold, Lockheed Martin Space Systems Company (United States)

Hennes Henniger, Deutsches Zentrum für Luft- und Raumfahrt e.V.

(Germany)

Warren Lewis, Met Office (United Kingdom)

Vladimir B. Markov, Advanced Systems \& Technologies, Inc. (United States)

Vincent Michau, ONERA (France)

Stuart D. Milner, University of Maryland, College Park (United States)

Dominic C. O'Brien, University of Oxford (United Kingdom)

Jacobus M. Oschmann, Jr., Ball Aerospace \& Technologies

Corporation (United States)

Ronald L. Phillips, Florida Space Institute (United States)

William S. Rabinovich, U.S. Naval Research Laboratory (United States)

Karin Stein, Fraunhofer-Institut für Optronik, Systemtechnik und Bildauswertung (Germany)

Michael T. Valley, Sandia National Laboratories (United States)

Thomas Weyrauch, University of Dayton (United States)

Otakar Wilfert, Brno University of Technology (Czech Republic) 
Session Chairs

1 Free-Space Optical Demonstration and Analysis

Christopher C. Davis, University of Maryland, College Park (United States)

Jaime A. Anguita, Universidad de Los Andes (Chile)

2 Free-Space Optical Models and Devices

Arun K. Majumdar, Naval Air Warfare Center Weapons Division (United States)

Christopher C. Davis, University of Maryland, College Park (United States)

3 Optical Propagation in Turbulence

Stephen M. Hammel, Space and Naval Warfare Systems Command (United States)

Jaime A. Anguita, Universidad de Los Andes (Chile)

4 Turbulence Models and Mitigation

Alexander M. J. van Eijk, TNO Defence, Security and Safety (Netherlands)

Mikhail I. Charnotskii, National Oceanic and Atmospheric Administration (United States)

$5 \quad$ Atmospheric Channel Modeling and Optimization

Matthew M. Bold, Lockheed Martin Space Systems Company (United States)

Gang Chen, University of California, Riverside (United States)

6 Adaptive Techniques and Channel Compensation

Heba Yuksel, Bogaziçi Üniv. (Turkey)

Christopher C. Davis, University of Maryland, College Park (United States) 